\title{
Eski Türk Edebiyatı Araştırmalarında Bir Kaynak Olarak İki Dilli Latin Harfli Tarihi Sözlükler*
}

\author{
Lokman TAŞKESENLİOĞLU**
}

\section{$\ddot{O} \mathbf{z}$}

Sözlükler, eski Türk edebiyatı araştırmalarında en önemli kaynaklardan biridir. Gerek Türkçe telif veya tercüme gerekse Arap̧̧a ve Farsça başta olmak üzere yabancı dillerde hazırlanan sözlükler, Türk edebiyatında Osmanlı Türkçesi ile oluşturulan metinlerle ilgili çalışmaların vazgeçilmez kaynakları olarak kabul edilmektedir.

Bu sözlükler içinde belki de en az kullanılanları Latin harfli iki dilli sözlüklerdir. Madde başlarının bugünkü alfabe ile verildiği bu tür sözlüklerde aslında telaffuz ile ilgili hususlar çok daha net olarak anlaşılmaktadır. Bu minvalde en çok kullanılan sözlükler Redhouse'un eserleri olmasına rağmen bunun haricinde başka sözlüklerden de yararlanmak mümkündür.

1928 öncesi Türkçeden yabancı dile sözlüklerde, madde başı Türkçe kelimelerin Latin harfli imlalarının kullanılması, bugün itibarıyla Osmanlı Türkçesi metinlerinin okunmasında yardımcı olabilmektedir. Bu nedenle harf inkılâbı öncesi basılan Türkçeden yabancı dile sözlükler taranmış, bu tür araştırmalara uygun olanlar tespit edilerek yazarlar ve eserler hakkında detaylı bilgi verilmiş̧ir.

Ayrıca taranan sözlüklerde Türkçenin harf inkılâbı öncesi söyleyiş özellikleriyle ilgili bazı hususlar da belirlenerek yerli ve yabancı sözlük yazarlarının eserlerinde bu hususa bakış gösterilmeye çalışılacaktır.

Anahtar Kelimeler: Eski Türk Edebiyatı, İki Dilli Tarihi Sözlükler, Osmanlı Türkçesi, Türkçe - Fransızca/ İngilizce/ Almanca Sözlükler, Sözlükçülük.

\footnotetext{
* Bu çalışma 16-20 Nisan 2018 tarihlerinde Ürgüp'te düzenlenen “ICOSS Sosyal Bilimler Konferansı"nda sunulan "Eski Türk Edebiyatı Metin İncelemelerine Alternatif Bir Kaynak Önerisi: İki Dilli Tarihi Sözlükler" başlıklı bildiriden geliştirilerek hazırlanmışıır.

** Dr. Öğr. Üyesi, Giresun Üniversitesi, Eğitim Fakültesi, Giresun.

Elmek: lokmantaskesenlioglu@gmail.com

Orcid: 0000-0002-1652-2538
} 


\title{
Bilingual Latin Alphabet Historical Dictionaries As An Source In Classical Turkish Literature Studies
}

\begin{abstract}
Dictionaries are among the most important resources in classical Turkish literature studies. In the Turkish literature, dictionaries in Turkish as well as foreign language dictionaries, primarily those in Arabic and Farsi are accepted as indispensable references to be used in studies related with texts in Ottoman Turkish.

Bilingual dictionaries written in Latin alphabet are among the least used dictionaries. Actually, issues related with pronunciation can be understood much more clearly when using these dictionaries which provide the lexical entries in today's alphabet. In this regard, it is possible to make use of other dictionaries even though Redhouse dictionaries are among the most frequently used dictionaries.

The use of Latin letter spellings of the Turkish word entries in pre-1928 Turkish to foreign language dictionaries may help us today read the texts written in Ottoman Turkish. Thus, Turkish into foreign language dictionaries printed prior to the alphabet reform have been scanned, those that are suitable for such studies have been determined and detailed information on these texts and their authors have been provided.

In addition, various factors related with the pronunciation of Turkish prior to the alphabet reform have also been determined in the scanned dictionaries, and the opinions of local and foreign dictionary writers on this issue shall be set forth.
\end{abstract}

Keywords: Classical Turkish Literature, Bilingual Historical Dictionaries, Ottoman Turkish, Turkish French/ English/ German Dictionary, Lexicography. 


\section{Extended Summary}

As it is known, dictionaries are an indispensable source of language and literature research. The affirmation of the richness of a language and its transformation into a literary language can only be realized by the determination of vocabulary. Increasing this wealth with different meaning relations is the most important factor that transforms that language into literary language. It is not a coincidence that dictionaries are the products of literature developed under the influence of Islam, the first works published with the establishment of the printing press and the first works after the revolutions of the letters.

Although the dictionaries, which have the same importance in literary researches, are enriched with contemporary researches and new examples, the value of historical dictionaries should not be ignored. It can be said that the use of historical dictionaries in the studies of ancient Turkish literature makes both Turkish and bilingual historical dictionaries indispensable sources since they are the only works that will present the mentality of the period to the researcher. Although historical dictionaries such as Ahterî-i Kebir, Vankulu Lügati, Kamusü’ül-Muhit, Burhan-1 Kat are frequently used in such studies, the studies on Turkish language are not limited to these.

Especially dictionaries from Turkish to foreign languages, namely dictionaries in foreign language, which is the head of Turkish, are noteworthy in terms of showing the spelling and pronunciation of words at that time by local and foreign lexicographs.

In this study where the usability of the historical dictionaries in which the Latin letters were read in the studies of transferring the Turkish texts in Ottoman letters into the Turkish texts in Latin letters and in the teaching of the Ottoman Turkish were examined, the dictionaries from the Turkish language written before 1928 were scanned and those works which were written in Turkish were used.

It was found that Arabic, Persian, French, English, German, Russian, Bulgarian, Greek, Armenian, Italian, Latin dictionaries were used as dictionaries from Turkish to foreign languages in the pre-letter period. Arabic, Persian, Russian, Armenian, Bulgarian and Greek dictionaries which cannot be used in this context are not included in the study. Italian and Latin dictionaries were excluded from 
the study because only Latin letters were used. A small number of manuscript dictionaries could not be included because they were not accessible.

Within this framework, 17 historical dictionaries which could be used in the researches of Old Turkish literature were determined. These dictionaries, which are prepared in Turkish-French, Turkish-German and Turkish-English and written Turkish words in Latin letters in the historical period, are seen as important sources for both language and literature researches.

The list of the dictionaries scanned for the study are as follows: Francisci a Mesgnien Meninski's Thesaurus Linguarum Orientalium, Turcicae, Arabicae, Persicae Lexicon Turcico-Arabico-Persicum, Artin Hindoğlu's - Hazine-i Lügat or Dictionnaire Abrégé Turc-Français, Thomas Xavier Bianchi's Elsine-i Türkiyye ve Franseviyyenin Lügati or Dictionnaire Turc-Français, James William Redhouse's Turkish-English Lexicon, Nassif Mallouf's Türkî ve Fransevî Lügatnâmesi or Dictionnaire Turc-Français, Charles Adrien Casimir Barbier de Meynard's Kitâb-1 Dürerü'l-Ummâniyye fi Lügati'l-Osmâniyye or Dictionnaire Turc-Français, Şemseddin Sami's Kâmûs-1 Fransevî or Dictionnaire Turc-Français, W. Wiesenthal's Turkish-French Small Dictionary or Petit Dictionnaire Turc - Français, Reali Yusuf's Dictionnaire Turc - Français, Ali Ferâz's Dictionnaire Turc-Français, Nicolas Murat's Dictionnaire Turc - Français, Galancızâde Hakkı Tevfik's Turkis-German Dictionary or Türkisch - Deutsches Wörterbuch, Ali Nazîmâ's Lügat-1 Tefeyyüz or Dictionnaire Tefeyyuz Ottoman-Français, J. Zenker's Dictionnaire Turc-Français, Nazaret Hilmi's Ottoman-French Pocket Dictionary, Murat Fr.'s Lexique TurcFrançais and Kemalpaşazâde Said's Kâmûs-1 Sait.

Dictionaries are indispensable sources of the old Turkish literature studies and Ottoman Turkish learning. Historical dictionaries, on the other hand, are once more important in this context. Dictionaries from Turkish to foreign languages are works that can be given as examples to these studies especially in terms of using Latin letters. In terms of both the words, the pronunciations translated into Latin letters and the Turkish equivalents, the dictionaries of Meninski, Bianchi, Redhouse, Barbier and Şemseddin Sami, especially Hindoğlu, can be used as an important source in the analysis of historical Turkish texts. For this reason, besides Redhouse and Meniski, new or just reprinted, these precious works of Hindoğlu, Bianchi, Barbier, Mallouf, Şemseddin Sami, Ali Nazîmâ should also be prepared in a way that can be reached by today's scientific world. 


\section{Giriş}

Sözlükler bilindiği üzere dil ve edebiyat araştırmalarının vazgeçilmez kaynaklarındandır. Bir dilin zenginliğinin tasdiki ve buna paralel olarak da edebiyat diline dönüşmesi ancak söz varlığının tespiti ile olabilmektedir. $\mathrm{Bu}$ zenginliğin farklı anlam ilişkileri ile artırılması, o dili edebiyat diline dönüştüren en önemli etmendir. Sözlüklerin, İslamiyet etkisinde gelişen edebiyatın ürünlerinden, matbaanın kuruluşu ile basılan ilk eserlerden ve harf inkılâbından sonra yapılan ilk çalışmalardan olmaları tesadüf değildir.

Edebiyat araştırmalarında da aynı ehemmiyete haiz olan sözlükler, çağdaş araştırmalar ve yeni örneklerle zenginleşse de özellikle tarihi sözlüklerin kıymeti göz ardı edilmemelidir. Eski Türk edebiyatı çalışmalarında tarihi sözlüklerin kullanılması, o dönemin zihniyetini araştırmacıya sunacak yegâne eserler oldukları için gerek Türkçe gerekse iki dilli tarihi sözlükleri vazgeçilmez kaynaklar haline getirdiği söylenebilir. Ahterî-i Kebir, Vankulu Lügati, Kamusü'ül-Muhit, Burhan-1 Katı gibi tarihi sözlükler bu tür araştırmalarda sıklıkla başvurulan eserler olmakla birlikte, Türk dili üzerine yapılan çalışmalar bunlarla sınırlı kalmamıştır.

Özellikle Türkçeden yabancı dillere sözlükler yani madde başı Türkçe olan yabancı dilde sözlükler, yerli ve yabancı leksikograflar tarafından kelimelerin o dönemde imlasının ve telaffuzunun gösterilmesi bakımından dikkat çekicidir.

Türk dilinin kelime varlığının tespiti noktasındaki ilk çalışma olan Dîvânü Lugati't-Türk'ün (Akalın 2008: 66) de Türkçeden yabancı dile bir sözlük olduğu gerçeğinden yola çıkarak eski Türk edebiyatı araştırmalarında kelimelerin okunuş ve anlamları ile ilgili yaşanan problemlere ek bir çözüm önerisi olarak bu sözlüklerdeki imla hususiyetlerinin kullanılabileceği ve diğer bazı noktalar örneklerle gösterilmeye çalışılacaktır. 


\section{Türkçeden Latin Harfli Yabancı Dillere Tarihi Sözlükler}

Arap harfli Türkçe metinlerin Latin harfli Türkçe metinlere aktarılması çalışmalarında ve Osmanlı Türkçesi öğretiminde sözcüklerin Latin harfli okunuşlarının verildiği tarihi sözlüklerin kullanılabilirliğinin ele alındığı bu çalışmada 1928 öncesinde kaleme alınan Türkçeden yabancı dile sözlükler taranmış, madde başı Türkçe olan bu eserler, kelimelerin açıklamalarında Latin harfli imlaların kullanılması bakımından incelenmiştir.

Harf inkılabı öncesi dönemde Türkçeden yabancı dillere sözlük olarak Arapça, Farsça, Fransızca, İngilizce, Almanca, Rusça, Bulgarca, Rumca, Ermenice, İtalyanca, Latince sözlükler olduğu tespit edilmiştir. Bu eserlerden bu bağlamda kullanılması mümkün olmayan yani Latin harflerinin kullanılmadığı Arapça, Farsça, Rusça, Ermenice, Bulgarca ve Rumca sözlükler çalışmaya dâhil edilmemiştir.

İtalyanca ve Latince sözlükler ise sadece Latin harfleri kullanıldığı için araştırmanın dışında tutulmuştur. Az sayıda olan el yazması sözlükler de erişimleri mümkün olmadığı için kapsama dâhil edilememiştir.

Bu minvalde incelenen eserlerin bir kısmı da cep sözlüğü olarak hazırlandığı ve gerek kelime gerekse anlam itibarıyla çalışmaya katkı sağlayacak nitelikte olmadığg için tahlilin dışında bırakılmıştır. Belirlenen bu çerçevede eski Türk edebiyatı araştırmalarında bu bağlamda kullanılabilecek olan 13 tarihi sözlük tespit edilmiştir. Türkçe-Fransızca, Türkçe-Almanca ve Türkçe-İngilizce olarak hazırlanan bu sözlüklerin farklı baskılarla sayısı 29'a kadar çıkmaktadır (Eminoğlu 2010; İlhan 2007). Tarihi dönemde Türkçe kelimelerin Latin harfleriyle yazıldığı bu sözlükler hem dil hem de edebiyat araştırmaları için önemli kaynaklar olarak görülmektedir.

\subsection{Francisci a Mesgnien Meninski - Thesaurus Linguarum Orientalium, Turcicae, Arabicae, Persicae Lexicon Turcico- Arabico-Persicum}

Francisci a Mesgnien Meninski, 1620'de Fransa'nın meşhur Alsace-Lorraine bölgesinde dünyaya gelen Leh asıllı bir dil âlimidir. Gençliğinde Roma'da zenginlikleriyle tanınan Cizvit rahiplerinin yanında felsefe, mantık, metafizik, fizik, matematik ve ilâhiyat eğitimi almıştır. Özellikle Arapça ve Farsçayı dönemin önemli isimlerinden Giattini'den Türkçeyi 1646'da Polonya'da bulunduğu 
dönemde W. Bieczynski'den öğrenmiştir (Yelten 2004: 144). İstanbul'a ilk defa 1653 'te elçilik heyetiyle birlikte gelen Meniski, bu dönemde de divan tercümanlarından Leh asıllı Ali Ufkî Bey'den ve Galata Mevlevîhânesi'ne mensup Ahmed isimli bir dervişten faydalanarak Türkçesini ilerletmiştir. 1657'de ikinci kez İstanbul'da görev almış, 1659'da Lehistan temsilcisi sıfatıyla Edirne'de IV. Mehmed ve diğer devlet adamları ile görüşmüştür. 1661'de Avusturya'nın hizmetine girerek Doğu dilleri mütercimliği görevini üstlenen Meninski, bu esnada bazı önemli siyasi olaylarda tercüman olarak görev yapmıştır. Son kez 1677'de imparator adına İstanbul'da gelen mütercim, 6 Eylül 1698'de Viyana'da ölmüştür (Yelten 2012: 581-582).

Lehçe, Fransızca, İtalyanca ve Latince gramer kitapları da bulunmakla beraber ona büyük şöhret ve saygınlık kazandıran en önemli eserleri, dönem itibarıyla ciddi bir dünya dili haline gelen Türkçenin Batı dünyasında öğrenilebilmesi için temel kaynaklar olarak hazırlanan çalışmalarıdır (Tulum 2011). 1680'de Viyana'da basılan üç ciltlik Türkçe-Latince (Almanca, Latince, İtalyanca, Galca ve Lehçe) sözlükle (Thesaurus Linguarum Orientalium, Turcicae, Arabicae, Persicae Lexicon Turcico-Arabico-Persicum 1-3) yine aynı yılda yayımladığı Türkçe dil bilgisi kitabı (Linguarum Orientalium Turcicae, Arabicae, Persicae Institutiones Seu Grammatica Turcica) ve 1687 'de basılan tek ciltlik LatinceTürkçe sözlüktür (Complementum thesauri linguarum orientalium, seu onomasticum Latino-Turcico-Arabico-Persicum) (Yağmur, 2014: 210). Eser daha sonra Viyana'da birkaç kez tekrar basılmış, Türkiye'de ise Mehmet Ölmez tarafindan birleştirilerek 6 cilt halinde tıpkıbasım olarak basılmıştır (Ölmez 1999).

Türkçe-Latince sözlüğün ön sözünde altmış civarında eserin ismini vererek onlardan yararlandığını belirten Meninski’nin yirmi yılda hazırladığı bu eser, yer yer Türkçe ile ilgili ön yargılı ifadeler barındırsa da Türk dilinin en büyük sözlükleri arasında yer almış, Avrupa'da sonraki yüzyıllarda yazılan hemen hemen bütün gramer ve sözlük çalışmalarının kaynağı olmakla beraber çeviri yazı sistemi ile ilgili önemli bir başvuru eseri olarak kabul edilmiştir (Tulum 2014: 101). Ayrıca mütercimi 18 ve 19. yüzyıllarda Türkçe üzerine çalışan dilcilerin örnek aldıkları ilim adamı haline getirmiştir. Bu yüzyıllarda hazırlanan sözlük ve gramerlerin hemen hepsinin ana kaynağı Meninski'nin çalışmalarıdır (Yelten 2004: 145). 
İki dilli bir sözlük olmamakla beraber Türkçeden yabancı dillere ilk sözlüklerden biridir. Türkçe, Arapça ve Farsça kökenli kelimelerin, bu dillerden eş anlamlıları ile birlikte Almanca, Latince, İtalyanca, Galca ve Lehçe gibi Avrupa dillerindeki karş1lıkları verilmiştir. Toplam 5 ciltlik külliyatın 3 cildini oluşturan bu sözlükte ayrıca kelimelerin kökenlerine ait bilgiler de verilmiş, kelimeler cümle içinde kullanılarak anlamları gösterilmiştir. Ayrıca Arap alfabesi ile yazılan bütün kelimelerin dikkatli bir şekilde Latin harfleriyle çeviri yazı ile verilmesi (Yelten 2012: 584), günümüz edebiyat incelemelerinde de önemli bir kaynak olarak kullanılabileceğini göstermektedir.

Meninski; Türkçe, Arapça ve Farsça madde başlarını Arap alfabesi ile verdikten sonra, geliştirdiği çeviri yazı alfabesi ile Latin harflerine aktarmış, ayrıca o kelimenin diğer dillerindeki karşılığını da eş anlamlı olarak verdikten sonra Avrupa dillerindeki karşılığını vermiştir. Örneğin "âfitâb" kelimesine "hurşid", "güneş" ve "şems" karşılıklarını verdikten sonra ilgili terimleri de açıklamıştır (Şekil 1.). "büyük" kelimesinin "büyük" veya "böyük" olarak verilen telaffuzundan sonra "ulu", "kebir", "azim” ve "büzürk" gibi Türkçe ve yabancı dillerde eş anlamlarının verilmesi de bu hususa diğer bir örnek olabilir (Şekil 2.):

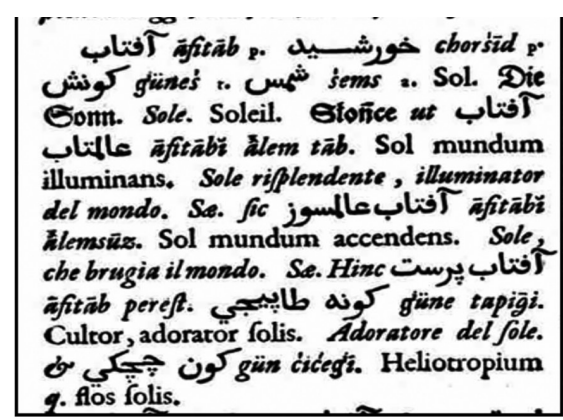

Şekil 1. ( Meniski 1680: 311).

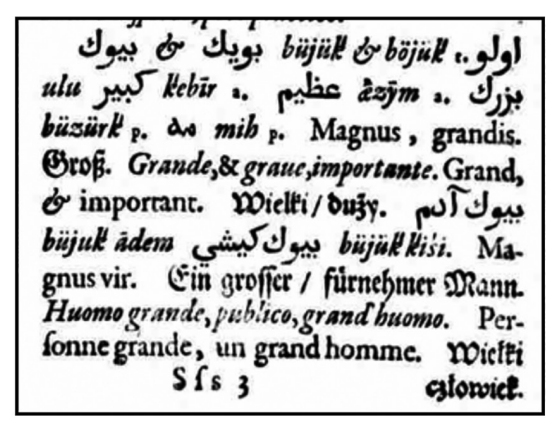

Şekil 2. (Meniski 1680: 1018).

Bununla birlikte eserde günümüz Türkçesindeki eklerde kullanılan dar ünlülerin 17. yüzyıldaki kullanımı da görülmektedir. "istibdâl” kelimesinin karşıl1ğ1 olarak tespit ettiği "değiştürmek" kelimesi, bu kullanıma sadece bir örnektir (Şekil 3.). Aynı husus "tıfl” kelimesinde "kiçirek veled, oğlancık" olarak tespit edilen karşılıkta da görülmektedir (Şekil 4.): 
1829'da yayımladığı Almanca açıklamalı Türk dil bilgisi kitabı olan Kitab-1 Sarf ve Lugat-i Türkî gibi gramer çalışmalarının ile birlikte, Hazine-i Lügat en önemli eserleridir. Özellikle 1838'de Viyana'da yayımlanan Dictionnaire Abrégé Turc-Français, gerek yöntemi gerekse kelime hazinesi bakımından çok kiymetli bir eserdir.

518 sayfadan oluşan ve her sayfada 2 sütun bulunan eserde Türkçe kökenli kelimelerin önce orijinal hali sonra da Latin harflerine aktarılmış durumu vardır. Türkçe kökenli olmayan kelimelerin pek çoğunun ise Türkçe karşılığı verildikten sonra Fransızca açıklaması verilmiştir. Bu yönüyle eser Osmanlı Türkçesi sözlüğ̈ olarak dahi kabul edilebilir. Ayrıca eserde kelimeler, örnek cümleler ve deyimler Latin ve Arap harfleri ile birlikte gösterilmiş, bunun yanında önemli miktarda arkaik kelimelere ve Anadolu ağızlarında kullanılan sözcüklere de yer verilmiştir.

“izdivac”, “izdiyad”, “isaet”, “esame”, “asan”, “esatin” (Şekil 7.) gibi kelimelerin okunuşu ve parantez içinde verilen karşılıkları dikkatle incelendiğinde günümüz Osmanlı Türkçesi sözlüklerinden farklı olmadığı görülmektedir:

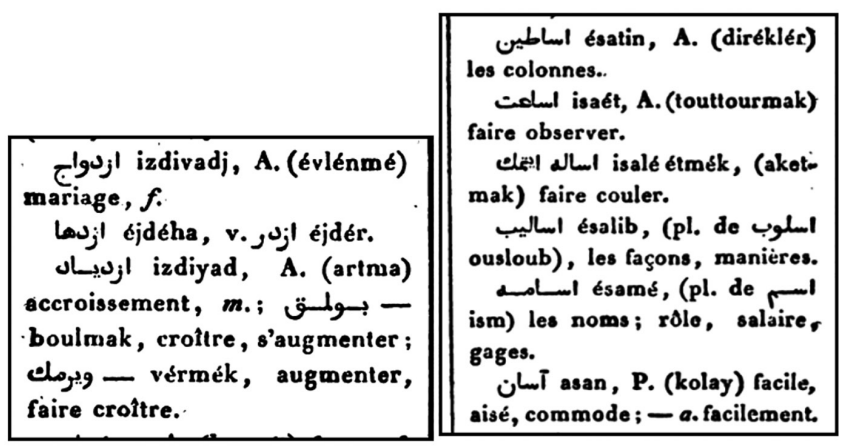

Şekil 7. (Hindoğlu 1838: 26-27).

Bu zengin kullanımın eserin neredeyse tamamına hâkim olduğu söylenebilir. "mütekebbir", "mütekellim”, "müteveffa" gibi kelimeler diğer örnekler olarak görülebilir (Şekil 8.): 


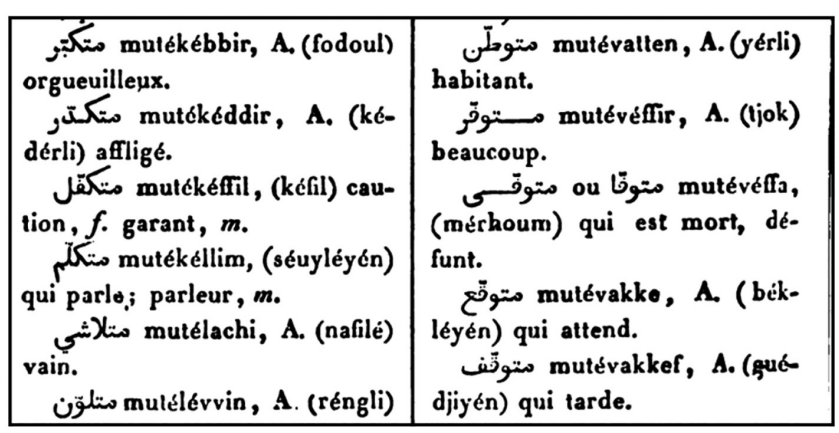

Şekil 8. (Hindoğlu 1838: 422).

Hindoğlu, sözlügünde de deyimler ve diğer yapılara yer vermiş, "meydan" maddesinde "meydan okumak", "meydan almak"; "vaz" kelimesinde "vaz gelmek", "vaz geçmek" (Şekil 9.); "yel” kelimesinde "yel kovan”, "kara yel” "şiriş yeli” (Şekil 10.) gibi anlam zenginliklerinden istifade etmiştir:

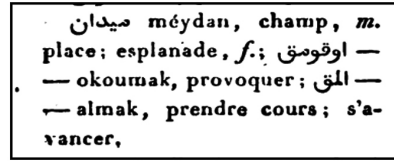

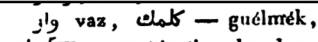
- guétjmék, abandonner, se désister, se déporter, laisser, quilter.

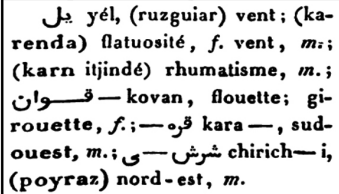

(poyraz) nord-est, $m$.

Şekil 9. (Hindoğlu 1838: 472, 487).

Şekil 10. (Hindoğlu 1838: 509).

Tüm bu hususlarla birlikte eserde "ebsem”, "abrak” gibi ancak derleme sözlüğünde yer alabilecek kelimeler ve arkaik yapılar da bulunmaktadır (Şekil 11.):

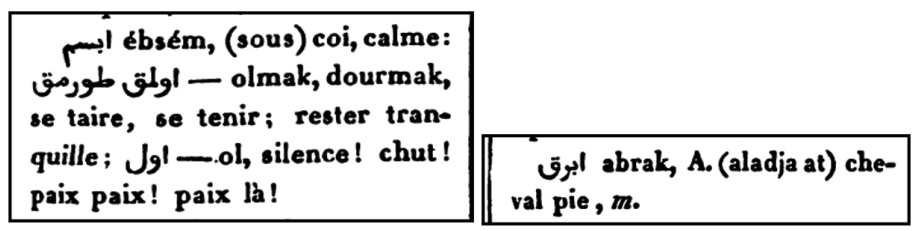




\subsection{Thomas Xavier Bianchi - Elsine-i Türkiyye ve Franse- viyyenin Lügati / Dictionnaire Turc-Français}

1783 'te Paris'te soylu ve zengin bir ailede doğan Bianchi, École des Langues Orientales'de okumuş, devrin önde gelen şarkiyatçılarından dersler almıştır. 1801'de burayı bitirince dil bilgisini ve pratiğini daha da ilerletmesi için İstanbul'daki Dil Oğlanları Mektebi'ne tercüman-öğrenci sıfatı ile gönderilmiş, burada Doğu dilleri ve kültüründeki engin bilgisiyle tanınan sefaret baş tercümanı Ruffin'den Türkçe ve Osmanlı örf ve âdetlerine dair dersler almıştır (Akün 1992: 117). İstanbul'da III. Selim devrinin önemli olaylarına şahit olan Bianchi, 1811'de İzmir Fransız konsolosluğunda dört yıl mütercim olarak görev almıștır. Daha sonra Hariciye Nezâreti'ndeki görevi için Paris'e dönmüş, çok önemli siyasi gelişmelerde tercümanlık yaparak geçirilen yirmi altı yıldan sonra mütercimlikten 1842'de emekli olmuştur. Pek çok alanda çalışmaları olan Avrupa'daki çok önemli eğitim kurumlarında Türkçe ve doğu dilleri ve kültürleri ile ilgili dersler veren 1851'de Hammer ve Redhouse ile birlikte Encümen-i Dâniş’e üye olarak seçilen Bianchi 1864'te Paris’te ölmüştür (Akün 1992: 117).

Bianchi, Osmanlıların tarihi, Türkçenin geçmişi gibi konular üzerinde eserler meydana getirmek yerine Avrupalılara Türkçeyi öğretmek, dönem itibarıyla bu husustaki ihtiyacı karşılamak ve zamanının Türkiye'sini tanıtmak yolunda çalışmalar yapmayı tercih etmiştir. Bu çalışmaları içinde kendisine asıl şöhret ve mevki sağlayan, geliştirmeye ömrünü vakfettiği lügat kitapları olmuştur (Akün 1992:118). Eserleri, kendisinden de istifade eden Şemseddin Sâmi'nin Dictionnaire Français-Turc (18821883), Dictionnaire Turc-Français (1885) ve Barbier de Meynard'ın Dictionnaire Turc-Français (I-II, Paris 1881-1886) çıkana kadar bu amaçla kullanılan en önemli eserler lügatler olmuştur.

Türkçe ile ilgili lügat, gramer ve bibliyografya türlerinde pek çok eser kaleme alan Bianchi, lügatlerinde sadece kelime ve anlamını vermekle yetinmemiş, Türkçeye dair görüşlerini de ifade etmiştir. 19. yüzyılda Osmanlı Devleti'nin yeni hamleler içinde yüksek bir gelişmeye aday olduğuna inandığı Türkçeyi Müslüman Doğu âlemi için politik ve ticarî sahada milletlerarası ortak bir dil saymıştır. Osmanlı İmparatorluğu'nun kapladığı geniş sahada Türkçenin Arapçadan çok daha yaygın ve hâkim oluşuna dikkat çekerek onun Ortadoğu'nun her tarafında idarî, siyasî ve ticarî münasebetlerde konuşulan ve yazılan yegâne dil olduğuna, Arapçanın ise Suriye ve Mısır'da sadece halkın dili seviyesinde bulunurken Türkçenin İran sarayı ve Hazar denizi kıyılarından öteye geniş bir sahada kullanıldığına işaret etmiş, diplomatik rolü ile Türkçeye Ortadoğu'da Arapça ve Farsça karşısında inkâr götürmez bir üstünlük tanımıştır. Ayrıca Türk edebiyatının zenginliği üzerinde durmuş, Türklerde mevcut şiir 
zevkine değinmiş ve Hammer'in İran edebiyatının sınırlı kaynaklarına göre değerlendirdiği Türk edebiyatının aslında çok daha büyük bir hazine olduğunu belirtmiştir (Akün 1992: 119).

Elsine-i Türkiyye ve Franseviyyenin Lügati (Dictionnaire Turc-Français), Fransız şarkiyatçısı Jean Daniel Kieffer'in1833'te ölümü nedeniyle yarım kalan çalışmayı bütünleştirerek tamamladığı Bianchi'nin en önemli eserlerinden biridir (Eren, 1998: 115). 1835-1837 arasında daha sonra da geliştirilerek 1850'de ve 1871 'de basılan eser, Şeyhülislâm Esad Efendi, Meninski, Hindoğlu gibi önemli şahsiyetlerin eserlerinden de faydalanılarak hazırlanmıştır. Bianchi bu eseri ile sadece Batılıların Türkçeyi öğrenmeleri için bir kaynak hazırlamamış, Osmanlı Türkçesinin Türklerce dahi ihmal edilegelmiş bir lügatini oluşturmuştur (Akün 1992: 120). Ayrıca Bianchi, iki ciltten oluşan eserinde çok geniş bir kelime hazinesi tespit etmiş, bunun yanında Osmanlı İmparatorluğu'nun yayıldı̆̆ı geniş coğrafî̀ sahaya ait yer isimlerine ve Osmanlı tarihi, örf ve âdetleriyle ilgili, her lügatte bulunamayacak ansiklopedik maddeler de vardir.

Eserin 1097 sayfa ve iki sütundan oluşan ilk cildinde I ve waras1, 1080 sayfa ve iki sütundan oluşan ikinci ciltte ise ش ve sarası kelimeler mevcuttur. Meninski ve Hindoğlu'dan farkı ise kelimelerin okunuşuna yer vermekle beraber anlamlarının verilmemesidir. "tebeddul”, "tebdil” gibi kelimeler okunuşları ile birlikte verilmiş, "teskin”de olduğu gibi (Şekil 12.) metinde verilen örnek ifadelerin okunuşları da Latin harfli olarak gösterilmiş fakat sadece Fransızca karşılıklara yer verilmiştir:

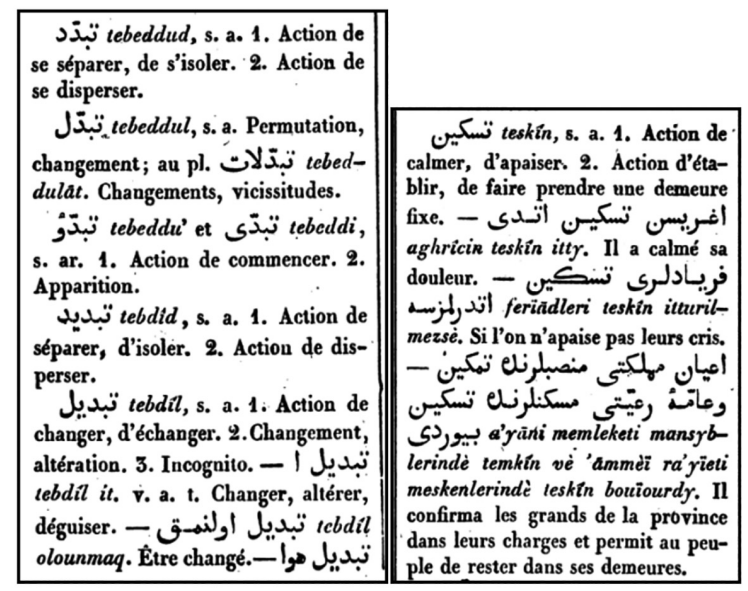

Şekil 12. (Bianchi 1850: 455, 491). 
"dil” kelimesini ise iki formda ele alarak anlamları numaralandırmıştır. $\mathrm{Bu}$ şekilde modern sözlüklerde olan bir tavır sergilendiğini söylemek mümkündür. Ayrıca "tatlı dilli”, “dil ile sokmak”, “dili sarmaşık, "dili dolaşık”, "dili ucunda olmak", "diller ile tabir olunmaz" gibi deyim ve ifadelerden de faydalanılmıştır (Şekil 13.):

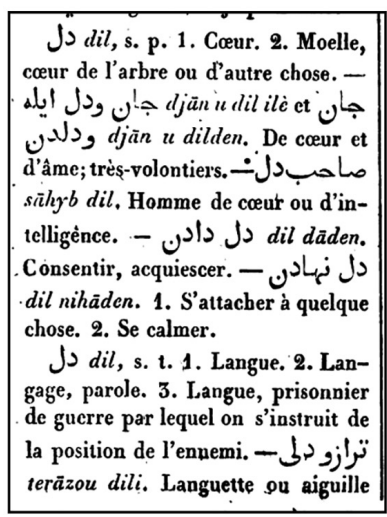

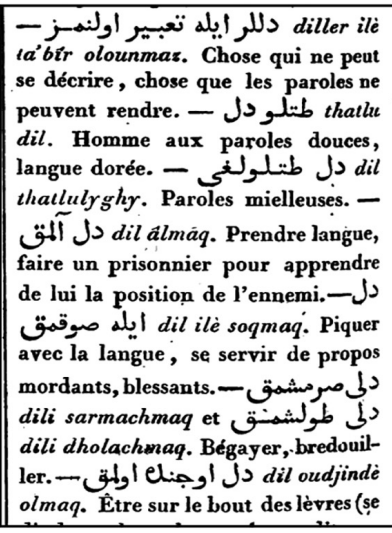

Şekil 13. (Bianchi 1850: 850).

Sözlük, bu özelliklerinin yanında "aparmak", “diriğg” (Şekil 14.) gibi arkaik kelimeler ve "geçme namerd köprüsünden ko aparsın su seni” gibi Türkçenin zenginliğinin nişanesi olan ifadeler de yer almaktadır:

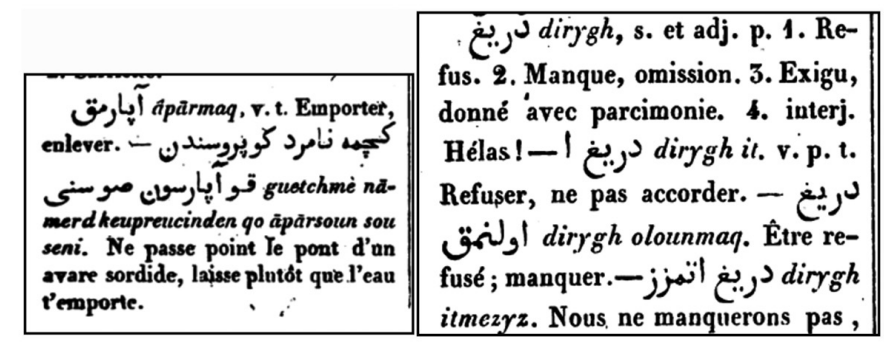

Şekil 14. (Bianchi 1850: 3, 832). 


\section{4. James William Redhouse - Türkçeden İngilizceye Lü- gat Kitabı/ Turkish and English Lexicon}

Yabancılar arasında Türk dilinin gelmiş geçmiş en büyük uzmanlarından biri olan William Redhouse 1811 'de Londra'da doğmuştur (Halman 1990: 299). Zor bir çocukluk geçirmiş, 1826' da kamarot olarak bir ticaret gemisi ile geldiği İstanbul'da kalmıştır. Kısa sürede büyük azimle Türkçe öğrenerek Bâbıâli Tercüme Odasında ve Mühendishâne-i Bahrî-i Hümâyun'da çalışmaya başlamıştır. Aynı zamanda eğitimine devam eden Redhouse, Türkçenin yanında Arapça, Farsça, Grekçe, Fransızca ve Almanca öğrenmiştir. 1830-1833 arasında Rusya'da bulunduğu zamanlarda ise Rusça ve Doğu Türkçesini de öğrenmiştir (Findley 2007: 523).

Tercüman ve muallim olarak İstanbul, Mısır, İngiltere ve başka Avrupa ülkelerinde görev yapmış, 1851 'de Encümen-i Dâniş üyeliğine seçilmiştir. Osmanlı memuriyetinden 1853'te emekli olunca İngiltere'ye dönerek Dışişleri Bakanlığı'nda Doğu dilleri mütercim-tercümanı olarak çalışmaya başlamıştır. Sultan Abdülmecid' in kendisine İftihar Nişanı verdiği Redhouse, 1888'de de Kraliçe Victoria'dan şövalyelik unvanı almıştır. Kendisine Cambridge Üniversitesi'nden fahrî doktora pâyesi de verilen Redhouse, 1892'de Londra'da ölmüştür (Findley 2007: 523).

Tercümanlık görevlerini yürütürken bir yandan Türk dili ile ilgili çalışmalar yürütmüş, kelimelerin anlamları ile birlikte kökenlerini de belirttiği Müntehabât-1 Lugat-1 Osmâniyye, İngilizce-Türkçe olarak hazırladığg1 Kitâb-1 Lehçetü’l-Meânî, Türk edebiyatından yaptığı tercümeleri ve yarım kalan Külliyyât-1 Azîziyye fi'lLugati'l-Osmâniyye (Kalafat 2017: 4) gibi pek çok eserinin yanında Türkçe-İngilizce hazırladığı sözlüğü de vardır. 1857'de Londra'da basılan Türkçeden İngilizceye Lügat Kitab1, Turkish and English Lexicon, daha sonra 1890'da Kitab-1 Maânî-i Lehçe li-James Redhouse el-İngilizî, A Turkish and English Lexicon Shewing the English Significations of the Turkish Terms adiyla geliştirilerek İstanbul'daki Amerikan Board heyeti tarafından basılmıştır (Halman 1990: 299). 1921 'den sonra yeniden basılmış, yeni harflerle de tekrar hazırlanarak günümüzde de aktif olarak kullanılan bir sözlük haline getirilmiştir.

Osmanlı Türkçesi metin incelemelerinde aktif olarak kullanılan eser, ilk baskıda İngilizce - Türkçe sözlük ile beraber 1152 sayfadan ibaretken 1890'da yapılan ikinci baskı tek cilt ve 2224 sayfalık boyutuyla oldukça hacim kazanmıştır.

Eserin ön sözünde Bianchi, Zenker, Meninski gibi şarkiyatçıların sözlük- 
lerinden ve Kamusü'l-Muhit, Burhan-1 Kat1, Lügat-1 Vankulu, S1hah-1 Cevheri, Ferheng-i Şuûrî gibi pek çok önemli eserden yararlandığını belirten Redhouse (1999: 11), otuz yıl boyunca bu çalışması üzerinde gayret sarf ettiğini belirtmiştir. Arap harflerine göre alfabetik olan sözlükte müellif aynı zamanda kelimenin kökünü de belirlemiş, Latin harfleriyle çeviri yazılı olarak kelimenin okunuşunu ve türünü göstermiştir (Kara 1990: 300). Madde baş1 100.000'in üzerindeki kelime, aynı zamanda 19. yüzyıldaki sosyal hayata dair bir kaynak olarak da görülmektedir (Maksudyan 2007: 38).

Bianchi'nin çalışmasında görülen eksiklik yani kelimelerin Türkçe anlamlarının verilmemesi bu sözlükte de mevcuttur. Ancak kelime sayısının üstünlüğü ve çeviri yazının çok daha üst sınıf bir dilci tarafından hazırlanmış olması, eserin ayırt edici özelliklerinden olduğu söylenebilir. "elzem”, “elsine”; “müteyessir”,

“müteheyyi”, (Şekil 15.) gibi örneklerde bu durum açıkça görülmektedir:

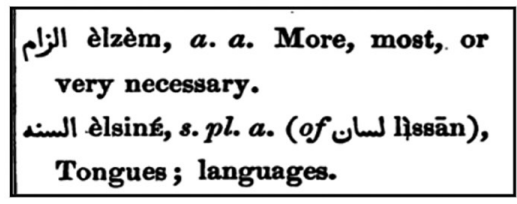

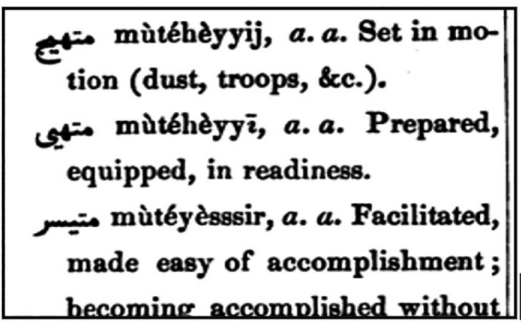

hecoming accomplished without

Şekil 15. (Redhouse 1857: 483, 984).

\section{5. Nassif Mallouf - Türkî ve Fransevî Lügatnâmesi/ Dic- tionnaire Turc-Français}

1823 'te Lübnan'da doğan Mallouf, Katolik bir ailede yetişmiş, öğretim hayatının büyük kısmını manastırda geçirmiş̧tir. 1844'te Fransızca öğrenmek üzere İzmir'e gelmiş, bu esnada Türkçe, Yunanca ve İtalyanca da öğrenmiştir. Kırım Savaşı esnasında çevirmen olarak Osmanlı ordusunda hizmet veren Mallouf, İngiliz ve Osmanlı hükümetleri emrinde İstanbul, Londra ve Bükreş’te tercüman olarak görev yapmaya devam etmiştir (Soydaş 2016: 373). 1865’te henüz genç ve üretken bir yaşta hayatını kaybetmiştir. 
Fransız şarkiyatçıların Hammer ve Bianchi'den sonra en büyük üstat olarak gördükleri Mallouf (1863: 7-9); Türk dili ile ilgili pek çok eser yayımlamış, konuşma kılavuzundan gramer kitabına, alfabe öğretiminden örnek metin tercümelerine kadar bu sahada farklı türde eserler kaleme almıştır (Soydaş 2016: 374-380).

1863 'te Paris'te basılan ve Türkî ve Fransevî Lügatnâmesi Dictionnaire Turc - Français adını taşıyan eser, Redhouse ve Bianchi’ye göre daha dar kapsamlı hazırlanmış olsa da özellikle kelimelerin birleşik fiil ve deyim içinde kullanılışlarını vermesi bakımından önemlidir. İki ciltten müteşekkil eserin birinci cildi I ve barası 1506, ikinci cilt $\varepsilon$ ve $s$ arası 1496 sayfadan oluşmaktadır. Diğer sözlüklerden şekil olarak farkı metnin tek sütun olarak hazırlanmış olmasıdır.

“ta’zir”, “ta'arruz”, "ta’rif” (Şekil 16.) gibi maddelerde kelime ve okunuşlarını verilen eser, aynı zamanda Osmanlı Türkçesi telaffuz kılavuzu olarak da düşülebilecek diğer sözlükler arasındadır:

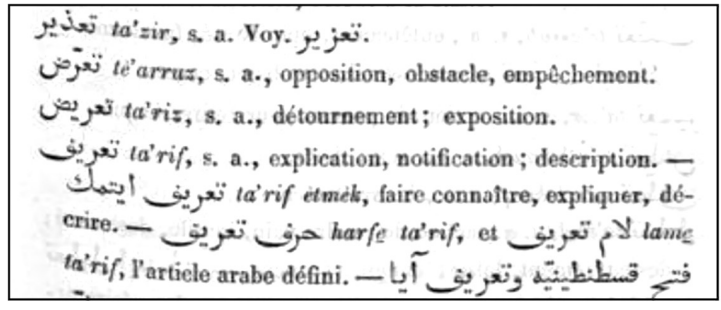

Şekil 16. (Mallouf 1863: 317).

"ictina etmek", "ictinab etmek", "ictihad", "ecdad" ve "ecir" (Şekil 17.) gibi kelimelerle de örnekler artırılabilir. Yazılışları benzeyen "ol" ve "evvel” gibi kelimeleri ayırt edebilmek için bazı harekelerden yararlanılması da dikkat çekicidir (Şekil 18.):

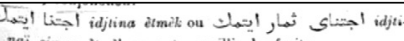
naï simar ètmèk, v. a..t., cueillir des fruits.

إجناب إئك idjtinab itmèk, v. a.-t., s'abstenir, éviter, fuir, so garder, s'éloigner.

أجتهidjtihad, s. a., soin, effort, guerre sacríe, opinion en matière de religion.

Jlậ èdjdad, s. a. pl. (de בَج djèdd), grands-pères, aieur, ancitres.

- 1 èdjr (comm. èdjir), s. a., récompense, rémunération,

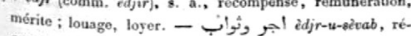
compense et rétribution.

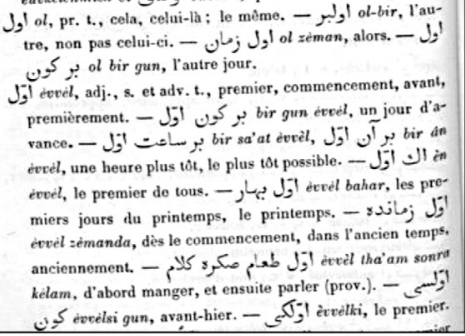


“takat getirmek”, “takatsiz olmak", "takatten düşmek” gibi deyimlere ve "sofra takımı", "çay takımı”, “yatak takımı”, "ayak takımı” gibi kelime guruplarına (Şekil 19.) sözlükte pek çok kez yer verilmiştir:

\begin{tabular}{|c|c|}
\hline 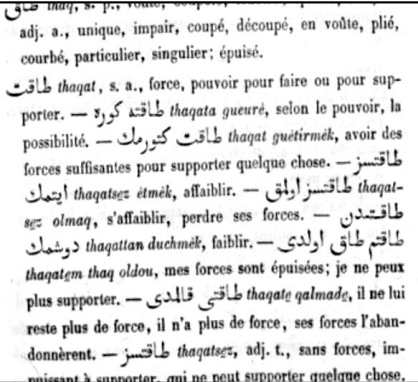 & 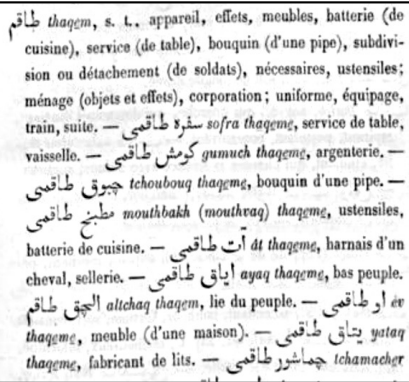 \\
\hline
\end{tabular}

Şekil 24. (Mallouf 1863: 734-735).

\section{6. Charles Adrien Casimir Barbier de Meynard - Kitâb-ı Dürerü'l-}

\section{Ummâniyye fi Lügati'l-Osmâniyye/ Dictionnaire Turc-Français}

Charles Adrien Casimir Barbier de Meynard, 1826'da İstanbul-Marsilya seferini yapan bir gemide doğmuştur. Ailesi hakkında, annesinin Tarabyalı olduğu ve anne tarafından dedesinin İstanbul'da doktorluk yaptığg dişında bilgi yoktur. Paris'te Collège Royal de Lois-le-Grand'da Arapça, Türkçe ve Farsça öğrenen Barbier; 1850'de Fransa'nın Kudüs başkonsolosluğunda, 1851'de Paris’te Journal Asiatique’te, 1854 'te, İran'da elçilik rehberliğinde görev yapmıştır. 1856'da Paris'e dönmek zorunda kalan ve bu arada Türkiye'yi de ziyaret eden Barbier, birlikte çalıştığ Jules Mohl'dan çok etkilenmiştir (Kallek 1992: 68). 1863 'ten sonra ölünceye kadar Yaşayan Doğu Dilleri Okulu'nda (Ecole des Langues Orientales Vivantes) Türkçe profesörü, Farsça profesörü ve Arapça profesörlüğü yapmış, bir müddet de müdürlüğünü üstlenmiştir.

1903 yılından itibaren sağlı̆̆ının bozulması sebebiyle kesintili olarak devam ettirebildiği öğretim faaliyetlerini bir müddet sonra durduran, ancak öğrencilerini odasında kabul etmeyi sürdüren Barbier 1908'de Paris’te ölmüştür (Kallek 1992: 69).

Türk, İran ve Arap edebiyatının önemli eserleri üzerinde çalışan ve onları Fransızcaya tercüme eden Babier'in en önemli eseri 1881-1886 arasında Paris’te 
yayımladığı Kitâb-1 Dürerü'l-Ummâniyye fi Lügati'l-Osmâniyye, Dictionnaire Turc-Français adını verdiği sözlügüdür. Klasik doğu medeniyetine ait eserlerin isimlerine benzeyen tarzda bir isim seçen müellif, eserinde Meninski, Mallouf, Bianchi, Redhouse, Ubicini gibi batılı şarkiyatçıların ve Ahmet Vefik Paşa, Ahmet Cevdet Paşa gibi Osmanlı dil bilimcilerinin çalışmalarından bahseden (1881: 5-8) Barbier'in mevcut Türkçe-Fransızca sözlüklere ek olarak hazırladığ en meşhur eseridir. Sözlükte Türkçe kökenli kelimeler, Farsça ve Arapçadan Osmanlı Türkçesine geçmiş kelimeler, arkaik kelimeler, atasözleri ve halk deyişleri, Osmanlı ülkesiyle ilgili coğrafî terimler yer almaktadır (Kallek 1992: 69). Eserin bir diğer farklı özelliği ise "Türkçe" veya "Türkî" yerine "Osmâniye" ifadesini tercih etmesidir.

İki cilt olarak basılan eserde birinci cilt I ve $د$ aras1 786 sayfa, ikinci cilt ذ ve $v$ arası 898 sayfadır. Her sayfada iki sütun bulunan eserin en dikkat çekici özelliği çok geniş bir kelime hazinesine sahip olmasıdır. Konuşma ve edebiyat dilinden bulunan kelimeler ile birlikte "apazlamak", "apal tapal”, “ipremek", "apalak" (Şekil 20.) gibi halk ağzından derlenen ve arkaik kelimenin bulunduğu da söylenebilir:

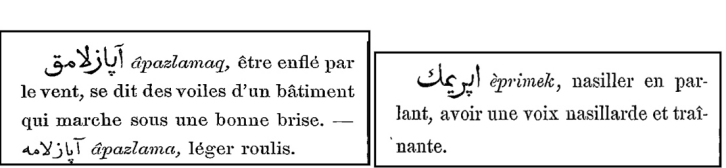

âpalaq, gros nourrisson; en fant à la mamelle frais et joufflu poupon.

إِ apal tapal, loc. populaire, très vite, en toute hâte.

Şekil 20. (Barbier 1881: 7).

Eserde atasözleri ve deyimlere de sik s1k yer verilmesi, Barbier'in sözlüğünün bir diğer önemli özelliğidir. "şair” maddesi "şaire lazım olan bir saz bir sözdür", "şair şairi, vaiz vaizi dinlemez”, "şair şeytanın kardaşıdır"; "karga" maddesi "şahin yerine karga, bülbül yerine serçe", "kuzgun kargaya karasın der", "karga karganın gözünü oymaz” (Şekil 21.) gibi ifadelerle süslenmiş ve zenginleştirilmiştir: 


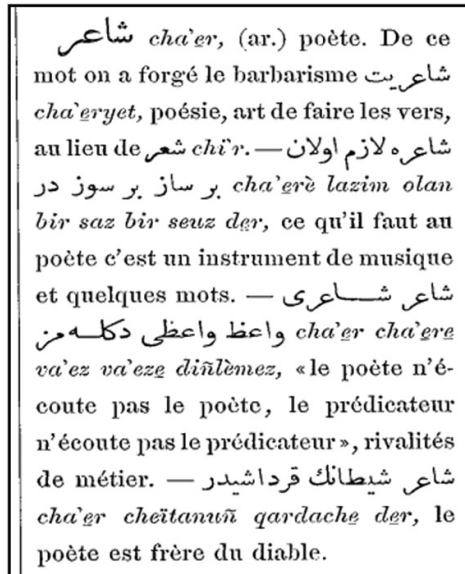

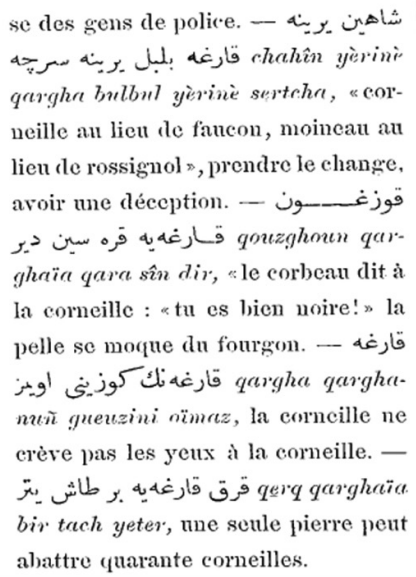

Şekil 21. (Barbier 1881: 131).

\section{7. Şemseddin Sami - Kâmûs-ı Fransevî/ Dictionnaire Turc-Français}

Bugün Yunanistan sınırları içinde olan Yanya’ya bağlı Fraşer köyünde doğan Şemseddin Sami, anne ve babasını küçük yaşta kaybetmesine rağmen öğrenimine devam etmiş önce Arapça ve Farsça, ortaöğreniminde ise Yanya' da Latince, Rumca, Fransızca ve İtalyanca öğrenmiştir (Uçman 2010: 519). 1872'de İstanbul'a giderek Matbuat Kalemi'ne girmiş, aynı zamanda aktif yayın hayatına dâhil olmuştur. Bu dönemde pek çok tercüme yapan ve gazetelerde tecrübe kazanan Şemseddin Sami, ayrıca ilk telif roman olan Taaşşuk-1 Talat ve Fıtnat'1 da kaleme almıştır. 1874'te Trablusgarb'a vilayet gazetesi için görevlendirildiğinde Avrupa'nın önemli kentlerini de ziyaret etmiştir.

Hayatının sonraki döneminde gazetecilik, matbaacılık, tercümanlık, tiyatroculuk gibi faaliyetlerin yanında ana çalışmalarını lügat ve ansiklopedi türleri etrafında şekillendirmiştir. 1889-1898 yılları arasında büyük emek harcayarak tek başına oluşturduğu Kamusü'l-Alâm (Levend 1969: 83-86) ve 1900'de yayımladığ1 modern Türk sözlükçülüğünün temel taşlarından ve Türk dilinin en önemli sözlüklerinden biri olan (Yavuzarslan 2009: 223; Gökçe 1998: 24-25), ayrıca özellikle "Türkçe Sözlük” adını verdiği Kamus-1 Türkî (Aksan 1998: 116) onun meşhur eserleridir. Orhun Abideleri ve Kutadgu Bilig gibi mühim eserler üzerinde çalışmalarını sürdürürken 1904'te vefat etmiştir (Hamit 2009: 18). 
Pek çok önemli eserinin yanı sıra 1885 'te hazırladığı Türkçe-Fransızca sözlüğü, Fransızca-Türkçe baskısı ile birlikte kendinden öncekileri kapsayan başarılı bir sözlüktür. Yazarın "Türkçeden Fransızcaya Lügat” olarak adlandırdığı (Şemseddin Sami 1885) Kâmûs-1 Fransevî, ölümünden sonra Diran Kelekyan tarafından gözden geçirilerek ve etimolojik bazı hususlar da eklenerek yeniden basılmıştır (Kelekyan 1911). Eser, arkaik kelimeleri de içermesi bakımından zengin bir eser olarak vücuda getirilse de hareke kullanılmaması, madde içindeki örnek ve birleşik yapıların telaffuzlarının verilmemeleri bazı zorluklara neden olmaktadir.

Şemseddin Sami, 1898'de aynı adla yaklaşık 35.000 kelime ihtiva eden Fransızca-Türkçe sözlük de kaleme almış, burada da kelimelere karşılık tespit ederken o günkü Türkçeyi en iyi şekilde değerlendirmeye çalışmıştır (Çiçek 2004: 26-27).

İki sütunluk 1208 sayfadan oluşan eser, Osmanlı Türkçesi metin incelemeleri bakımından çok da pratik olmayan bir çeviri yazı ile Latin harflerine aktarılmışsa da "gök" ve "ateş" (Şekil 22.) madde başlarına dair açıklamaların "gökden düşmek", "göğün direkleri alınmak", “ateş almak”, "ateş püskürmek" gibi deyim ve birleşik yapıları içermesi bakımından önemlidir:
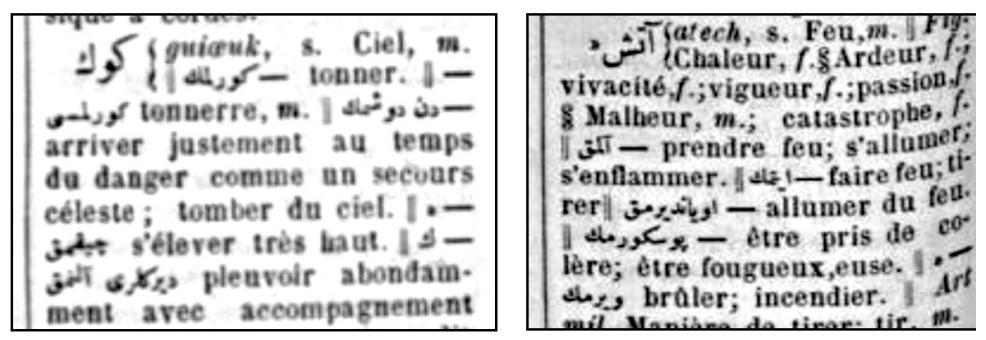

Şekil 22. (Şemseddin Sami 1885: 917, 4).

Daha önce hazırlanan Türkçe-Fransızca sözlüklerdekilere benzer bir tarzda "müctenib", “müceddid”, "mütevelli”, “mütehafit" (Şekil 23.) gibi kelimelerin Latin harfli telaffuzlarının verilmesinin esere aynı zamanda Osmanlı Türkçesi metin incelemeleri için de kullanılabilecek bir sözlük değeri kattığı söylenebilir: 


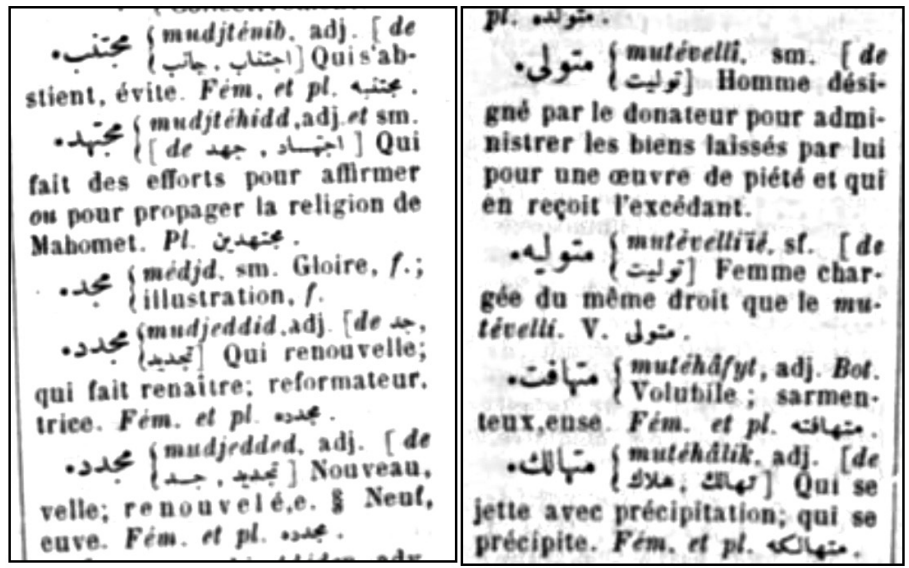

Şekil 23. (Şemseddin Sami 1885: 981, 978).

"tülek", "tülemek” (Şekil 24.) gibi konuşma dilinde sık kullanılmayan kelimelerin varlığı da sözlüğün çok daha kapsamlı bir amaç çerçevesinde hazırlanmış olduğunu göstermektedir. "hükm", "hakem” ve "hikem” (Şekil 25.) gibi yazı1ışları benzer kelimelerin tespiti ve tarihi metin incelemelerinde faydalanılması bakımından da eserin oldukça faydalı olabileceği söylenebilir:

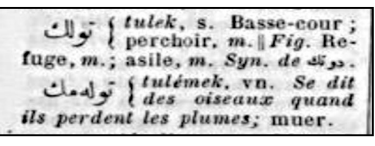

Şekil 24. (Şemseddin Sami 1885: 362).
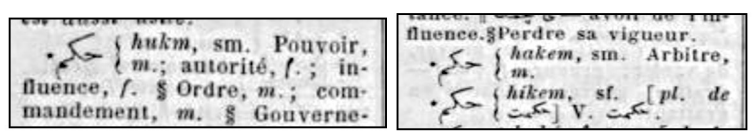

Şekil 25. (Şemseddin Sami 1885: 440).

\subsection{W. Wiesenthal - Türkçeden Fransızcaya Küçük Lügat/ Petit Dictionnaire Turc - Français}

Kaynaklarda hakkında herhangi bir bilgiye rastlanmayan W. Wiesenthal tarafından hazırlanan eser, 1887'de İstanbul'da basılmıştır. Eserin sunuş kısmında dahi yazar hakkında bilgi verilmeyen ve Türkçeden Fransızcaya Küçük Lügat adını taşıyan sözlük, konuşma sözlüğü olarak hazırlandığı için diğer sözlüklere göre daha az kelime içermektedir. Eserin en dikkat çekici özelliği madde başı kelimelerin Arap harfleri ile yazılıp herhangi bir telaffuz veya imla ile ilgili hu- 
susiyetin Latin harfleri ile verilmeden Fransızca karşılığının belirtilmesidir. İki sütundan oluşan 628 sayfalık eserin, bu yönüyle araştırma bağlamında kullanılması mümkün değildir.

Küçük bir cep sözlüğü olarak meydana getirilen eserde kelime içinde "baş" örneğinde olduğu gibi “başa çıkmak”, "başdan çıkmak” (Şekil 26.) gibi deyimlere yer verilmişse de veya "ağır” (Şekil 26.) örneğinde olduğu gibi kelimeden türeyen yapılar ifade edilmişse de bu yapılar dahi sadece Arap harfleri ile verilmiş, telaffuzları gösterilmemiştir:

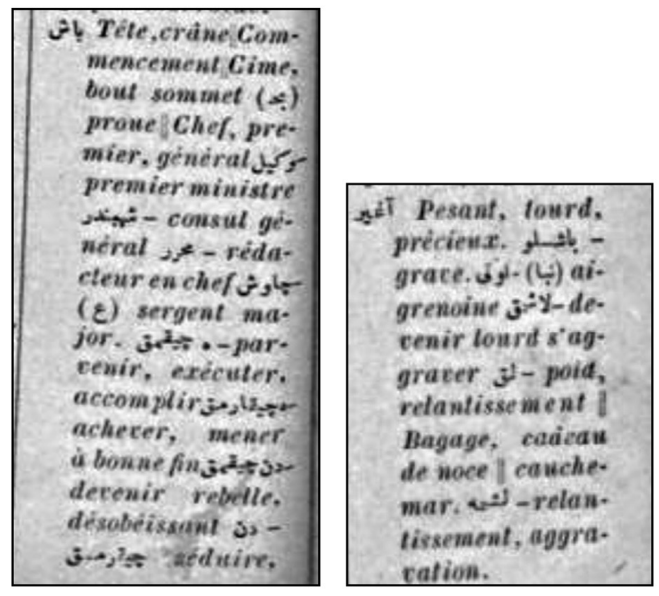

Şekil 26. (Wiesenthal 1887: 62,19).

\subsection{Reali Yusuf - Dictionnaire Turc - Français}

Eserin, Fransızca olarak hazırlanan sunuş kısmından anlaşıldığı üzere II. Abdülhamid döneminde yaşamış, uzun süre Fransa'da da bulunmuş bir Fransızca muallimi olan Reali Yusuf; Osmanlı Devletinin 1453'ten sonra imparatorluğa dönüşmesi ile birlikte Avrupa dilleri ile Türkçenin daha çok yakınlaşmaya başladığı beyan etmiş, bu nedenle Avrupalıların Türkçe öğrenebileceği bir sözlük hazırlamak istediğini söylemiştir. Kaynaklarda hakkında başka bir bilgiye rastlanamayan Reali Yusuf, bu nedenle sözlüğü farklı bir şekilde dizinlediğini ifade etmiştir (1888: VIII-XV).

İstanbul'da 1888'de basılan Dictionnaire Turc - Français ise dizinlenmesi bakımından diğer eserlerden ayrılmaktadır. Kelimenin önce Latin sonra Arap 
harfleri ile yazılması dizinlemeyi de Latin harflerine göre yapmayı zorunlu k1lmıştır. İki cilt olarak hazırlanan eserde birinci cilt a ve k arası 642 sayfa, ikinci cilt k ve z arası 694 sayfadır. İki sütun olarak hazırlanan sözlüğün Latin harfleri ile yazılan bir Türkçe sözlük olarak daha çok Türkçe öğrenen yabancılar için kaleme alınmış olduğu söylenebilir. Bu yönüyle Osmanlı Türkçesi metinlerin incelenmesinde esas olan kaynakların özelliklerini taşımamaktadır. Verilen "abdest” ve "müteessir" örneklerinde durum görülmektedir (Şekil 27):

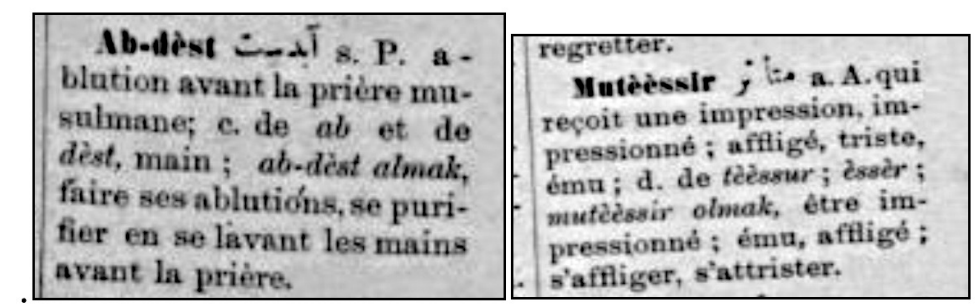

Şekil 27. (Reali Yusuf 1888: 2, 834).

“çocukluk", "mayhoş" ve "çözülmek” (Şekil 28.) gibi örneklerden de anlaşılacağı üzere oldukça karmaşık bir çeviri yazı sistemi uygulayan yazarın, yabancıların Türkçeyi doğru telaffuz etmeli için gayret sarf ettiği söylenebilir:

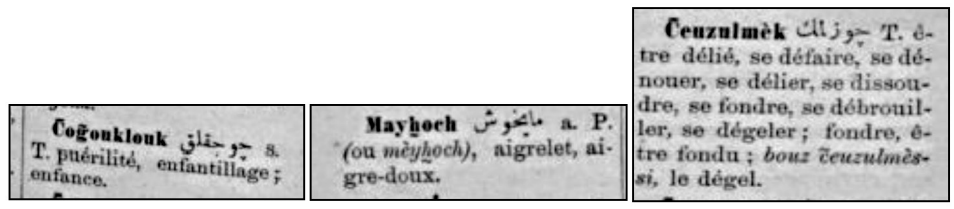

Şekil 28. (Reali Yusuf 1888: 173, 688, 147)

\subsection{Ali Ferâz - Türkçeden Fransızcaya Mükemmel Lügat-ı} Ferâz

Kaynaklarda herhangi bir bilgiye rastlanamayan Ali Ferâz tarafindan kaleme alınan, diğer örneklere göre çok daha dar kapsamlı olan eser, kelimenin genellikle tek anlamının verildiği küçük bir sözlüktür. Tek sütun halinde 728 sayfadan oluşan ve İstanbul'da 1890'da basılan Türkçeden Fransızcaya Lügat-1 Ferâz, daha 
çok konuşma dilinde kullanılan basit ifadeleri barındırmaktadır. Ayrıca çeviri yazı şekli de önceki örneklere göre oldukça karmaşıktır. Verilen örneklerde de bu durum dikkati çekmektedir (Şekil 29.):

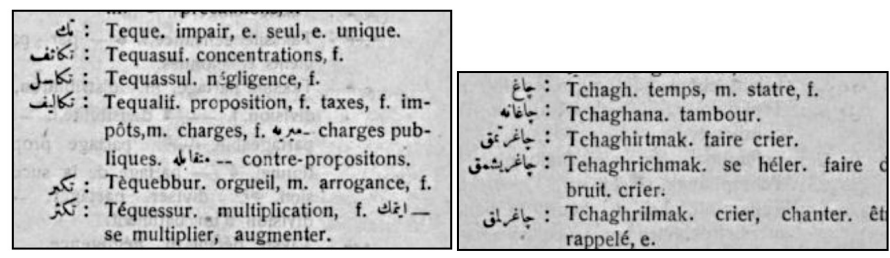

Şekil 29. (Ali Ferâz 1927: 180, 226).

\subsection{Nicolas Murat - Dictionnaire Turc - Français}

Lügat-1 Ferâz gibi konuşma temelli hazırlanmış bir sözlüktür. Kaynaklarda hakkında herhangi bir bilgiye rastlanamayan Nicolas Murat tarafindan hazırlanan ve 1903 'te İstanbul'da basılan Dictionnaire Turc - Français'de kısmen de olsa kelimeler cümle içinde kullanılmıştır. İki sütun halinde 318 sayfadan oluşan eserde çeviri, dizinleme veya yazarla ilgili hiçbir bilgi verilmemiş, sadece indeks kısmı hazırlanmıştır. Konuşma diline yönelik hazırlandığı için seçilen kelimeler ve ifadeler de bu yönde oluşturulmuştur (Şekil 30.):

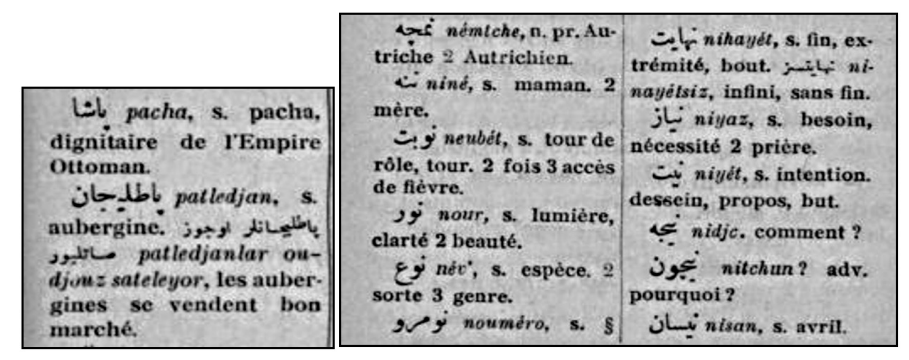

Şekil 30. (Nicolas Murat 1903: 93, 294).

\subsection{Galancızâde Hakkı Tevfik - Türkçeden Almancaya Lügat Kitabı, Türkisch - Deutsches Wörterbuch}

Dönemin Alman Bankası (Deutsche Bank) hukuk dairesi muavinlerinden Galancızâde Hakkı Tevfik tarafından kaleme alınmıştır. Harf inkılabı öncesinde 
hazırlanan tek Türkçe-Almanca sözlük olan ve Leipzig'de 1907'de basılan Türkçeden Almancaya Lügat Kitabı, Türkisch - Deutsches Wörterbuch adını taşıyan eser 1917'de ve 1921'de tekrar basılmıştır. Birinci Dünya Savaşı'nın sebep olduğu politik gelişmelerle Almancanın öğrenilmesi hususunda ortaya çıkan ihtiyacı karşılamak için kaleme alınan eser, bazı farklı alfabe özellikleri içermesi bakımından önemlidir.

Üç sütun olarak hazırlanan 388 sayfalık eser Türkçeden Almancaya olduğu için farklı sesler içermekte ve bazı imla hususlarında ön plana çıkmaktadır. Almancada da bulunan "ö" ve "ü", eserden bu amaçla yararlanmaya vesile olmuştur (Şekil 31.). Fakat kelimeler basit anlamları ile verilmiş, herhangi bir yapı veya cümle ile kullanılmamıştır. Bu yönleriyle zengin bir sözlük olmasa da kelime sayısı bakımından Osmanlı Türkçesi metin incelemelerinde müracaat edilebileceği söylenebilir (Şekil 31.):

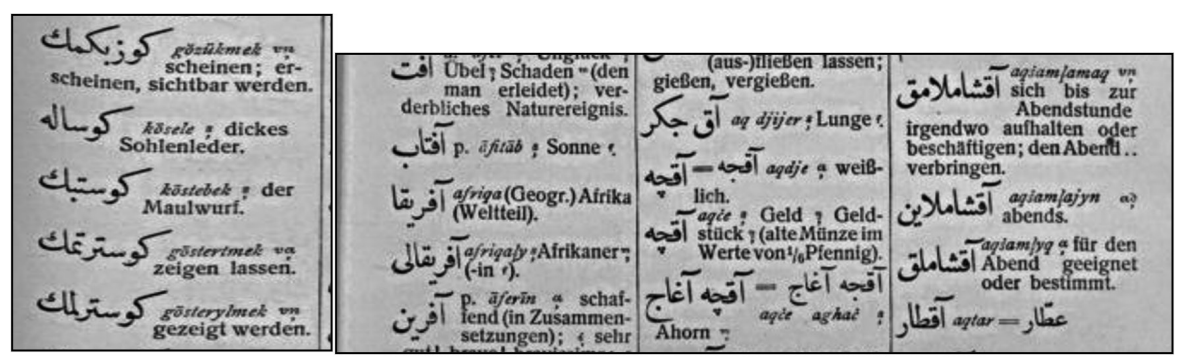

Şekil 31. (Hakk1 Tevfik 1917: 287, 7).

\subsection{Ali Nazîmâ-Lügat-ı Tefeyyüz/ Dictionnaire Tefeyyuz Ottoman- Français}

1861 'de İstanbul'da doğan Ali Nazîmâ'nın gerçek adı Mehmed Ali'dir. Babası Hilâl-i Ahmer'in kurucularından doktor yarbay Ahmed Servet Bey, dedesi doktor Ârif Bey'dir. Soyadı kanunu ile Yiğit soyadını almıştır (Yiğit 2004: 14-15).

Üsküdar'da tamamladığı ilk ve orta öğreniminin ardından önce Galatasaray Mekteb-i Sultânîsi'ne sonra Mekteb-i Mülkiye'ye gitmiş̧tir 1881'de Galatasaray Mekteb-i Sultânîsi Türkçe ve Arapça hocalığı yapan Ali Nazîmâ, aynı zamanda Mekteb-i Mülkiye'de Fransızca hocalığını da sürdürmüştür. 1888'de sultânî ho- 
calarından Necib Bey ile beraber devrin tanınmış eğitimci ve ediplerinden Mehmed Zihni Efendi, Muallim Feyzi Efendi ve Muallim Nâci gibi eğitimcilerin de hocalık yaptığı Mekteb-i Edeb adıyla özel bir okul açmışsa da kısa süre sonra 1890'da Necip Bey'in ölümü nedeniyle okulu kapatmıştır (Kahraman 2006: 453).

Daha sonra Mekteb-i Mülkiye, Mercan İdâdîsi, Dârü'l-Muallimîn, Dârü'lMuallimât, Vefa İdâdîsi Kadastro Mektebi, Nişantaşı Sultânîsi, Amerikan Erkek ve K1z kolejleri ve Saint Benoit Lisesi gibi dönemin en önemli okullarında Fransızca ve Türkçe dersleri vermiş, Dârülfünun'un Ulûm-i Tabîiyye ve Dîniyye ile Elsine bölümlerinde görev yapmıştır (Ülkütaşır 1977: 114-115). 1935'te İstanbul' da vefat edinceye kadar eğitim öğretim alanında pek çok farklı kurumda görev yapan Ali Nazîmâ, yüzden fazla ders kitabı, sözlük ve tercüme kaleme almıştır (Kahraman 2006: 454).

Bu sözlüklerden biri de İstanbul'da 1910 ve 1912'de basılan Türkçe-Fransızca bir okul sözlüğü olarak hazırlanan Lügat-1 Tefeyyüz'dür. Cep boy olarak 960 sayfa olarak basılan ve "Türkçe” yerine "Osmanlıcadan Fransızcaya Lügat" olarak adlandırılan eser, bu nedenle daha dar kapsamlı ve sınırlıdır. Fakat âlim bir lügatçi tarafından kaleme alındığı için bağlamdaki ihtiyaca cevap verecek nitelikte hazırlandığı söylenebilir.

Küçük boy olmasına rağmen eserde oldukça fazla madde başı bulunması dikkati çekmektedir. Arap harfli olarak verilen kelimelerin daha sonra Latin harfli okunuşları gösterilmiş, sonra da kısaca Fransızca karşılığı okuyucuya sunulmuştur. Eski Türk edebiyatı metin incelemelerinde bugün de başvurulabilecek eserde "can atmak", "söz atmak" gibi deyimlere de yer verilmiştir (Şekil 32.):

\begin{tabular}{|c|c|c|c|}
\hline 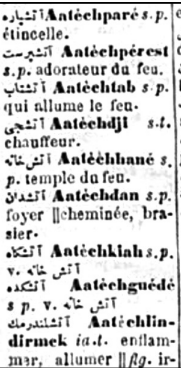 & 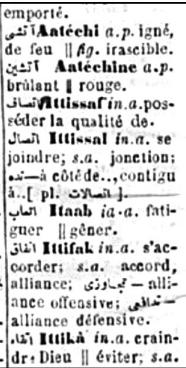 & 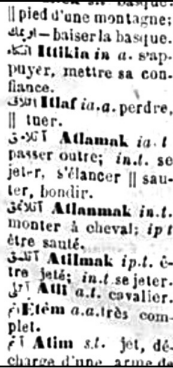 & 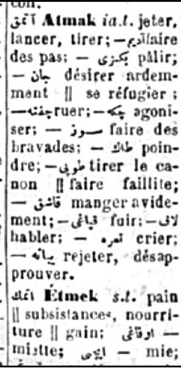 \\
\hline
\end{tabular}


Ayrıca J. Zenker'in 1866-1876 yılları arasında yayımlanan Dictionnaire Turc-Français, Nazaret Hilmi'nin 1886'da İstanbul'da basılan Osmanlıcadan Fransızcaya Cep Lügati, Murat Fr. tarafindan hazırlanan ve İstanbulda 1891'de basılan Lexique Turc-Français ve Kemalpaşazâde Said'in 1918'de adını vererek hazırladığı Kâmûs-1 Sait bu çerçevede değerlendirilebilecek, eski Türk edebiyatı metin incelemelerinde ve Osmanlı Türkçesi öğretiminde kullanılabilecek diğer kaynak eserlerdir.

\section{Sonuç}

Sözlükler, günümüzde eski Türk edebiyatı incelemelerinin ve Osmanlı Türkçesi öğreniminin vazgeçilmez kaynaklarıdır. Tarihsel sözlükler ise metinlerin oluşturulduğu dönem itibarıyla bu bağlamda bir kat daha büyük önem arz etmektedir. Türkçeden yabancı dile sözlükler ise özellikle Latin harflerinin kullanılması bakımından bu çalışmalara örnek olarak verilebilecek eserlerdir. Hem kelimeleri, hem Latin harflerine aktarılmış telaffuzlarını hem de Türkçe karşılıklarını içermesi bakımından başta Hindoğlu'nun lügati olmak üzere Meninski, Bianchi, Redhouse, Barbier ve Şemseddin Sami’nin sözlükleri, ilgisiz gibi görünse de tarihi Türkçe metinlerin tahlilinde önemli birer kaynak olarak kullanılabilirler. $\mathrm{Bu}$ nedenle yeni veya tıpkıbasımları yapılan Redhouse ve Meninski'nin yanında özellikle Hindoğlu, Bianchi, Barbier, Mallouf, Şemseddin Sami, Ali Nazîmâ'nın bu kıymetli çalışmaları da günümüz bilim dünyasının ulaşabileceği bir şekilde yeniden hazırlanmalıdır. 


\section{Kaynakça}

Akalın, Şükrü Haluk (2008). Binyıl Önce Binyıl Sonra Kâşgarlı Mahmud ve Divanü Lugati tTürk. Ankara: Türk Dil Kurumu Yayınları.

Aksan, Doğan (1998). “Türklerde Sözlükçülük, Bugün Türkiye'de Sözlük”, Kebikeç, 6, 115-118.

Akün, Ömer Faruk (1992). "Bianchi, Thomas-Xavier”, Türkiye Diyanet Vakfi İslam Ansiklopedisi (DIA), C. 6, Türkiye Diyanet Vakfı Yayınevi, İstanbul, s.117-120.

Ali Ferâz (1927). Türkçeden Fransızcaya Mükemmel Lügat-ı Ferâz. İstanbul: Ahmed Kâmil Matbaas1.

Ali Nazîmâ (1910). Lügat-ı Tefeyyüz Dictionnaire Tefeyyuz Ottoman-Français. İstanbul: Kaspar Matbaas1.

Barbier de Meynard, Charles Adrien Casimir (1881). Kitâb-ı Dürerü'l-Ummâniyye fi Lügati'lOsmâniyye/ Dictionnaire Turc-Français. Paris.

Bianchi, Thomas Xavier ve Kieffer, Jean Daniel (1850). Elsine-i Türkiyye ve Franseviyyenin Lügati Dictionnaire Turc - Français. Paris.

Çiçek, Ali (2004). “Sözlük Bilimi Açısından Kamus-1 Fransevi’nin İncelenmesi”, AÜ Türkiyat Araștırmaları Enstitüsü Dergisi. 23, s.25-32.

Eminoğlu, Emin (2010). Türk Dilinin Sözlükleri ve Sözlükçülük Kaynakçası. Sivas: Asitan Yayınları.

Eren, Hasan (1998). Türklük Bilimi Sözlüğü. Ankara: Türk Dil Kurumu Yayınları.

Ertaş, Kasım (2016). “Türk Dili ve Ermeniler: Osmanlı'nın Ermeni Dilbilimcileri”, JASSS, $53,151-162$.

Findley, Carter Vaughn (2007). "Redhouse, Sir James William”, Türkiye Diyanet Vakfi İslam Ansiklopedisi (DİA), C. 34, Türkiye Diyanet Vakfı Yayınevi, İstanbul, s.523.

Gökçe, Aziz (1998). Türkiye Türkçesinin Tarihi Sözlükleri. Ankara: Kebikeç Yayınları.

Hakk1 Tevfik, Galancızâde (1917). Türkçeden Almancaya Lügat Kitabı, Türkisch - Deutsches Wörterbuch. Leipzig.

Halman, Talat Sait (1990). "Redhouse, Sir James", Türk Dili ve Edebiyatı Ansiklopedisi (TDEA), C. 7, Dergâh Yayınevi, İstanbul, s.299-300.

Hamit, Furkan (2009). Şemseddin Sami ve Nev-Usûl Sarf-ı Türkî. Ankara: Türk Dil Kurumu Yayınlar1.

Hindoğlu, Artin (1838). Hazine-i Lügat - Dictionnaire Abrégé Turc-Français. Vienne: Chez F. Beck Libraire.

İlhan, Nadir (2007). Geçmişten Günümüze Sözlükçülük Geleneği ve Türk Dili Sözlükleri. Elazığ: Manas Yayıncılık. 
Kahraman, Âlim (2006). "Nazîmâ", Türkiye Diyanet Vakfi İslam Ansiklopedisi (DİA), C. 32, Türkiye Diyanet Vakfi Yayınevi, İstanbul, s.453-454.

Kalafat, Şermin (2017). “Bir Sözlüksel Bilmece: Redhouse’un Kayıp Türkçe Sözlüğüne Ne Oldu?", Bilig, 82, s. 1-40.

Kallek, Cengiz (1992). "Bardier de Meynard, Casimir Adrien", Türkiye Diyanet Vakfi Íslam Ansiklopedisi (DIA), C. 5, Türkiye Diyanet Vakfı Yayınevi, İstanbul, s.68-69.

Kara, İsmail (1990). "Redhouse Sözlügü̈, Türk Dili ve Edebiyatı Ansiklopedisi (TDEA), C. 7, Dergâh Yayınevi, İstanbul, s.300-301.

Kelekyan, Diran (1911). Kâmûs-ı Fransevî Dictionnaire Turc-Français. İstanbul: Mihran Matbaas1.

Levend, Agâh Sirrı (1969). Semsettin Sami. Ankara: Türk Dil Kurumu Yayınları.

Maksudyan, Nazan (2007). "Bir Sözlükten Büyülenmek”, Toplumsal Tarih, 158, s.34-39.

Mallouf, Nassif (1863). Türkî ve Fransevî Lügatnâmesi Dictionnarie Turk - Français, Paris.

Meninski, Francisci a Mesgnien (1680), Thesaurus Linguarum Orientalum Turcicae, Arabicae, Persicae Lexicon Turcico-Arabico-Persicum. Vienne.

Nicolas Murat (1903). Dictionnaire Turc - Français. İstanbul. Levant Herald.

Ölmez, Mehmet (1999). Franciscus a Mesgnien Meninski Thesaurus Linguarum Orientalium Turcicae - Arabico - Persicum Lexicon / Meninski Sözlüğ̈̈, Tipkıbasım. Ankara: Türk Dilleri Araştırmaları Dizisi.

Pamukciyan, Kevork (2003). Zamanlar, Mekanlar, Insanlar. İstanbul: Aras Yayınc1l1k.

Reali Yusuf (1888). Dictionnaire Turc - Français. İstanbul: Ebuzziya Matbaas1.

Redhouse, Sir James William (1857). Türkçeden İnilizceye Lügat Kitabl, Turkish and English Lexicon. London.

Redhouse, Sir James William (1999). Redhouse Türkçe/Osmanlıca- İngilizce Sözlük. İstanbul: Sev Yayıncilik.

Soydaş, Hakan (2016). "Şarkiyatçı Nassif Mallouf'un Eserleri ve Çocuk Edebiyatında Bir Mihenk Taş1: Kitâb-1 Der-Hakk-1 Sibyân ve Sabâvet", Türkiyat Mecmuası, 26/2, s. 371383.

Şemseddin Sâmi (1885). Kâmûs-ı Fransevî Dictionnaire Turc-Français. İstanbul: Mihran Matbaas1.

Tulum, Mertol (2014). “Meninski’ye Göre XVII. Yüzyıl İstanbul Türkcesi’nde /I/ Ünlüsü”, Türkiyat Mecmuası, 24/Bahar, 99-112.

Uçman, Abdullah (2010). "Şemseddin Sâmi”, Türkiye Diyanet Vakfi İslam Ansiklopedisi (DİA), C. 38, Türkiye Diyanet Vakfi Yayınevi, İstanbul, s.519-523. 
Ülkütaşır, M. Şakir (1977). “Ali Nazimâ”, Türk Dili ve Edebiyatı Ansiklopedisi (TDEA), C. 1, Dergâh Yayınevi, İstanbul, s.114-115.

Wiesenthal, W. (1887). Türkçeden Fransızcaya Küçük Lügat Petit Dictionnaire Turc-Français. İstanbul: Mahmud Bey Matbaas1.

Yağmur, Ömer (2014). "Erken Dönem Türkçe Transkripsiyon Metinleri ve Bunların Dil Araştırmaları Açısından Önemi”, FSM İlmî Araştırmalar ve Toplum Bilimleri Dergisi. 4, 201-217.

Yavuzarslan, Paşa (2009). Osmanlı Dönemi Türk Sözlükçülügü̈. Ankara: Tiydem Yayınları.

Yelten, Muhammet (2004). "Meninski, François a Mesgnien”, Türkiye Diyanet Vakfi İslam Ansiklopedisi (DIA), C. 29, Türkiye Diyanet Vakfi Yayınevi, İstanbul, s.144-145.

Yelten, Muhammet (2012). "Meninski, François de Mesgnien ve Eserleri”, İstanbul Üniversitesi Edebiyat Fakültesi Türk Dili ve Edebiyatı Dergisi, 30, 581-589.

Yiğit, Nuyan (2004). Atatürk'le Otuz Yll: İbrahim Süreyya Yiğit'in Öyküsü, İstanbul: Remzi Kitabevi. 